\title{
Assessing The Governance Model And Fraud Prevention Based on Pesantren
}

\author{
Kurniawan ${ }^{1}$, Nizarul Alim ${ }^{2}$, Rita Yuliana ${ }^{3}$ \\ kurniawan.se@gmail.com ${ }^{1}$ \\ Universitas Trunojoyo Madura, Jl Raya Telang, Kamal, Bangkalan, Jawa Timur, P.O. \\ Box 2, Indonesia
}

\begin{abstract}
Islamic boarding schools in Indonesia are developing not only managing education but also managing various businesses that are utilized in addition to the entrepreneurial practices of the santr also commercial social involvement involving thirdparty investments originating from santri guardians. This study aims to identify the characteristics of typical pesantren model and governance instruments and the role of good governance in fraud prevention efforts. Using qualitative research with descriptive case study type at Riyadlul Jannah Islamic Boarding School (PP Rijan) Pacet Mojokerto Regency, primary data collection through in-depth interviews, observation and secondary data from documentation, then validation using triangulation and analyzed through transcription and coding processes. In this study several results were found, firstly, PP Rijan had 2 (two) organizations to manage its activities, namely the Bina Insani Foundation and PT Rijan Dynamic Selaras which became a unique characteristic of governance in the selection of managers by using 3 (three) specific criteria namely: ethic, ethical and loyal. Second, there are 6 characteristics in typical pesantren governance, among others: transparency, accountability, professionalism, social responsibility, sharia oversight function and manners. What distinguishes the principles of governance in general are: (1) professional character which places someone who is not only skillful but also devoted and seeks blessing, (2) social responsibility, the existence of the hut is able to foster tranquility, caring and goodness (grace), (3) sharia oversight function, which examines the suitability and compliance with the Shari'a before and when the business is run (4) manners, the cultivation of good moral values is sourced from the book of ta'lim muta'alim and morals of lil banin wa lil banat bring activity managers to always maintain good behavior. It was concluded that the typical pesantren governance that manages a variety of commercial businesses does not leave the principles of good governance according to the KNKG except the principle of independence. Local wisdom typical governance of Islamic boarding schools in managing business groups based on religiosity plays a role in efforts to prevent fraud in the form of mitigation as a form of anti-fraud strategy where managers do not have to be monitored so they are afraid not to commit fraud.
\end{abstract}

Kata kunci: typical governance, multi-business pesantren, fraud prevention.

\section{Pendahuluan}

Pondok pesantren adalah lembaga agama Islam yang memiliki karakter tersendiri, memungkinkan lebih banyak fleksibilitas untuk mengandalkan inovasi guna mewujudkan relevansi pendidikan yang sejalan dengan perkembangan ilmu pengetahuan dan teknologi. Tujuan sekolah seperti itu menekankan pada pengembangan karakter wirausaha dan pekerjaan 
sosial [1]. Pondok Pesantren juga merupakan salah satu bentuk institusi yang dikenal sebagai lembaga pendidikan dan dakwah Islam dan banyak dilakukan tempat di seantero negeri[2]. Pondok pesantren pada dasarnya memiliki fungsi meningkatkan kecerdasan bangsa, baik ilmu pengetahuan, keterampilan maupun moral. Namun, fungsi kontrol moral dan pengetahuan agamalah yang selama ini melekat dengan sistem pendidikan pondok pesantren. Fungsi ini juga telah mengantarkan pondok pesantren menjadi institusi penting yang dilirik oleh semua kalangan masyarakat dalam menghadapi kemajuan ilmu pengetahuan dan derasnya arus informasi di era globalisasi [3].

Menurut Republika, pesantren tidak hanya mengelola lembaga pendidikan, kini banyak pondok pesantren yang juga mengelola lembaga usaha yang berskala besar. Bahkan di Jawa Timur telah terbentuk Serikat Bisnis Pesantren di antaranya Pesantren Tebuireng Jombang, Pesantren Zainul Hasan Genggong, Pondok Pesantren An Nur 1, Pondok Pesantren An Nur 2, Pesantren Annuqayah Madura, Pesantren Sidogiri, Pesantren Sunan Drajad, Pesantren Nurul Jadid Probolinggo, Pesantren Bahrul Ulum Jombang, dan Pesantren Al Fitrah Surabaya[4]. Pesantren mempunyai potensi besar, baik dalam bidang pemikiran maupun ekonomi. Pesantren seringkali mengalami pasang surut akibat tidak adanya pengelolaan secara serius terhadap potensi yang dimilikinya. Potensi ekonomi pesantren merupakan potensi lokal yang seharusnya bisa dikembangkan dengan baik [5].

Pedoman Akuntansi Pesantren menyatakan bahwa terdapat dua jenis unit usaha di pondok pesantren. Pertama, pondok pesantren memiliki unit usaha yang dikelola secara mandiri yang masih merupakan bagian dari badan hukum yayasan pondok pesantren. Unit usaha strategis tersebut termasuk dalam entitas pelaporan pondok pesantren. Kedua, unit usaha dari pondok pesantren juga dapat berdiri sendiri sebagai badan hukum terpisah, seperti dalam bentuk koperasi, perseroan terbatas, dan bentuk badan hukum lainnya. Unit usaha tersebut tidak termasuk dalam cakupan entitas pelaporan pondok pesantren [6]. Unit usaha pesantren jenis kedua memiliki ciri melibatkan pihak lain dalam kepemilikan dan sumber modal atas usaha yang dijalankan. Di dalam unit usaha jenis ini pengguna dana atau eksekutif yang menjalankan bisnis memiliki kewajiban untuk menyampaikan laporan kegiatan usaha dan kinerjanya.

Kewajiban untuk membuat dan menyampaikan laporan, memberikan jaminan kepada pemilik modal bahwa bisnis yang dilakukan menjalankan prinsip-prinsip bisnis yaitu prinsip transparansi, prinsip akuntabilitas dan prinsip keberlanjutan usaha. Laporan yang disampaikan dipergunakan untuk mengukur kinerja usaha. Pelaporan keuangan, merupakan pengejawantahan dari konsep good governance (tata kelola yang baik) yakni prinsip transparansi dan akuntabilitas. Prinsip-prinsip tata kelola yang baik telah ditetapkan oleh Komite Nasional Kebijakan Governance (KKNG) meliputi lima pilar antara lain: keterbukaan (transparency), akuntabilitas (accountability), pertanggungjawaban (responsibility), independensi (independency), dan kewajaran (fairness) [7].

Konsep tata kelola yang baik baru populer di Asia. Konsep ini relatif berkembang sejak tahun 1990-an. Konsep tata kelola yang baik baru dikenal di Inggris pada tahun 1992. Negaranegara maju yang tergabung dalam kelompok OECD (kelompok negara-negara maju di Eropa Barat dan Amerika Utara) mempraktikkan pada tahun 1999 [8].

Penelitian tentang tata kelola telah dilakukan pada perusahaan pemerintahan [9]. Beberapa penelitian telah menguji dan meneliti tata kelola khas antara lain tata kelola perusahaan keluarga (family governance) [10], tata kelola pengelolaan wakaf[11] dan tata kelola bank Islam [12]. Perbedaan hubungan agensi dalam kepemilikan dan kendali membutuhkan pengembangan tata kelola. 
Di antara penelitian-penelitian tentang tatakelola dengan lokus penelitian lembaga nonformal adalah penelitian yang dilakukan Oktafia dan Basith menyebutkan bahwa implementasi prinsip-prinsip tata kelola yang baik, yaitu keterbukaan, akuntabilitas, pertanggungjawaban dan kewajaran di Pondok Pesantren As-Syafi'iyah Buduran Sidoarjo sudah cukup baik dengan diindikasikan oleh perkembangan pondok pesantren yang terus mengalami peningkatan, tetapi pesantren harus lebih mengoptimalkan prinsip independensi untuk kesuksesan di masa mendatang[13]. Sedangkan menurut [14] bahwa penggunaan akuntansi di pondok pesantren dipercaya lebih banyak mengandung muatan lokal yakni muatan religius dan kemuliaan.

Salah satu pondok pesantren di Indonesia yang berkembang menjadi organisasi yang mengelola bermacam-macam kegiatan sosial, pendidikan dan berbagai usaha komersial adalah sebuah pesantren bernama PP Riyadlul Jannah yang berkedudukan di Pacet Mojokerto pondok ini mengelola pendidikan setingkat SMP, SMA dan penguruan tinggi (Sekolah Tinggi Ilmu Ekonomi Syariah-STIES Riyadlul Jannah), lembaga sosial panti asuhan yatim piatu. Berbagai bisnis komersial yang dimiliki dan dikelola di antaranya adalah toko swalayan, biro perjalanan wisata-umroh, butik online, rumah potong ayam (RPA), perikanan, perkebunan, percetakan, rumah makan cepat saji-fried chicken, delapan unit usaha kuliner tradisional lesehan, dan lebih dari dua puluh unit modern food. Karena pondok pesantren ini mengelola berbagai bisnis dan berbagai kegiatan sosial maka dapat diistilahkan sebagai pesantren multisosial multi bisnis. Dari informasi yang terdapat pada laman web PP Riyadlul Jannah (2017) pesantren yang dipimpin oleh KH. Mahfud Syaubari ini dari usaha-usaha komersial formal yang dilakukan dalam sebulan memiliki omzet lebih dari Rp 3 miliar.

Berdasarkan fenomena dan dinamika tersebut, penelitian ini bertujuan untuk menelisik komponen tata kelola model pesantren yang mengelola berbagai kegiatan sosial (multi sosial) dan berbagai usaha komersial (multibisnis). Penelitian ini memilih pesantren Riyadlul Jannah Pacet Mojokerto sebagai situs penelitian karena perkembangan pesantren tersebut saat tidak hanya sebagai lembaga dakwah, pendidikan tetapi juga menjadi organisasi sosial dan memilliki banyak unit bisnis termasuk biro travel umroh, guna mendukung kemandirian.

\section{Metode Penelitian}

Penelitian ini menggunakan desain penelitian kualitatif studi kasus tipe deskriptif yang digunakan untuk mendeskripsikan fenomena yang terjadi tentang tata kelola dengan situs penelitian ini adalah di pondok pesantren Riyadlul Jannah (PP Rijan) Pacet Kabupaten Mojokerto karena pondok ini merupakan merupakan salah satu pondok pesantren yang besar dilihat dari sisi organisasi, jumlah santri dan juga aset yang mereka miliki serta memenuhi kriteria sebagai pesantren multisosial usaha.

Pengumpulan data primer dalam penelitian ini melalui wawancara, observasi partisipasi pasif. Sedangkan data sekunder diperoleh berupa dokumen resmi yang berkaitan dengan objek menggunakan metode tinjauan kepustakaan, mengakses situs-situs, berita-berita, maupun website, buku, serta data sekunder yang digunakan untuk mendukung penelitian ini.

Uji validitas yang digunakan dalam penelitian ini adalah triangulasi meliputi: triangulasi sumber, triangulasi metode, dan triangulasi data. Informan dalam penelitian ini adalah pengurus Yayasan Ponpes Riyadlul Jannah H. M. Ainur Rofiq(MAR), Pengelola Rijan Dinamika Selaras (RDS) H. Ahsanul Milal (HAM) dan masyarakat sekitar PP Rijan. 


\section{Pembahasan}

Analisis data ditujukan untuk untuk mengetahui dan mendeskripsikan karakteristik tata kelola pada pondok pesantren Riyadlul Jannah Pacet Mojokerto. Proses analisis data dalam penelitian ini adalah sebagai berikut: membuat transkrip data hasil wawancara dengan informan, menyusun data hasil wawancara dari informan, melaksanakan penyandian (coding) dan mengklasifikasi data, serta menggabung dengan data hasil observasi dan analisis dokumen untuk mendapatkan gambaran pondok pesantren Riyadlul Jannah saat ini sekaligus mengidentifikasi dan menganalisis kendala yang dihadapi saat ini.

\section{Selayang Pandang Riyadlul Jannah}

Mendengar nama Pacet di Mojokerto identik dengan kawasan wisata. Di daerah inilah Pondok Pesantren Riyadlul Jannah berdiri, tepatnya di sisi Barat Jalan Raya Mojosari, Pacet kilometer 19 Desa Pacet, Kecamatan, Pacet, Kabupaten Mojokerto di lereng Gunung Welirang. Dari Kota Mojokerto bisa melalui rute Mojokerto - Dlanggu - Pacet dengan jarak tempuh kurang lebih 30 kilometer, atau bisa lewat rute Mojokerto - Mojosari - Pacet yang berjarak sekitar 40 kilometer. Jika berangkat dari Surabaya dapat melewat rute Sepanjang Krian - Mojosari - Pacet, atau bisa juga melalui rute Sidoarjo - Wonoayu - Mojosari - Pacet. Jarak tempuh sekitar 60 kilometer dari Surabaya. Apabila berangkat dari arah Pasuruan dan kota-kota di wilayah Timur Jawa Timur bisa melalui rute Gempol- Pandaan- PrigenTrawas- Pacet, atau lewat rute Gempol- Mojosari- Pacet. Apabila berangkat dari Malang bisa melalui rute Pandaan - Prigen - Trawas - Pacet, atau jika kendaraan kondisi laik jalan dan fit bisa melalui rute Malang- Batu - Cangar - Pacet.

Lingkungan tempat berdirinya pondok memiliki panorama alam yang indah, sejuk dan asri di lingkungan sekitar ditunjang tata ruang bangunan dan kondisi fisik pesantren yang bersih, indah dan teratur membuat betah untuk menikmatinya dan sangat representatif untuk mengaji dan nyantri. Makna dari nama Riyadlul Jannah adalah pertamanan surga ini nampaknya tidak berlebihan, dibangun di atas tanah seluas kurang lebih $9.000 \mathrm{~m}^{2}$. Nama tersebut juga merupakan pengharapan bagi pendiri agar situs pondok ini bisa menjadi represntasi taman surga. Kondisi fisik pesantren yang megah dan indah dengan bangunanbangunan bertingkat di atas kolam-kolam ikan, dan perkebunan pesantren yang menghijau dengan berbagai tanaman pangan dan sayuran.

\section{Sejarah Pesantren Riyadlul Jannah}

Berawal dari keinginan tokoh - tokoh masyarakat desa Pacet untuk membuat lembaga pesantren sebagai wadah pendidikan agama di daerah tersebut, sekaligus sebagai benteng dari pengaruh - pengaruh negatif wisatawan pada waktu itu,. Tahun 1985 KH Mahfudz Syaubari MA (dikenal dengan Kiai Pud oleh masyarakat Mojokerto) yang sebelumnya lebih dulu sudah mengajar di berbagai pesantren di luar Jawa diminta untuk mendirikan Pondok Pesantren yang menempati sebuah rumah salah satu tokoh masyarakat Pacet, pesantren tersebut diberi nama Darussalam. Hingga dibangunlah dua lokal baru disekitar Masjid Al Hidayah Pacet $( \pm 300 \mathrm{~m}$ dari lokasi pesantren sekarang ) pada tahun 1987. Saat itu DR. As sayyid Muhammad bin Alawy Al Maliki yang merupakan guru dari KH. Mahfudz Syaubari melakukan kunjungan dan menyarankan kepada beliau untuk mencari tempat yang lebih representatif untuk sebuah pesantren. Pada tahun 1990 saran ini terealisasi dengan dibelinya tanah yang menjadi lokasi pesantren sekarang. Dimulailah pembangunan pesantren baru dengan nama Riyadlul Jannah, yang merupakan nama pemberian dari Dr. As sayyid Muhammad bin Alawy Al Maliki. Pe lan 
tapi pasti pembangunan pesantren baru itupun berjalan. Santri berangsur - angsur pindah lokasi dari pesantren lama ke lokasi pesantren baru. Lokasi pesantren lama difungsikan untuk Panti Asuhan Yatim Piatu dan Dhuafa yang dikelola para santri alumni.

Figur KH. Mahfudz Syaubari MA kiai yang berkepribadian kuat, tegas, dan disiplin ini tak bisa dilepaskan dari karakter pondok. Beliau lahir pada tanggal 20 November 1954 di Demak Jawa Tengah. Nyantri di berbagai Pondok pesantren besar di Jawa Tengah terakhir di Pesantren Al-Falah Ploso Kediri Jawa Timur sebelum mendalami ilmu dari Dr. Assayyid Muhammad Bin Alawy Al Maliki di Makkah. KH. Mahfudz Syaubari adalah figur ulama intelektual yang sangat kuat menanamkan jiwa kemandirian pada semua santri, baik secara pribadi atau lembaga terbukti dengan pembangunan dan perawatan pondok yang beliau tangani sendiri dengan melibatkan seluruh santri tanpa terkecuali. Bangunan - bangunan yang berdiri dilingkungan pesantren kebanyakan adalah hasil karya santri. Para santri mendapat arahan dari beliau sesuai dengan bakat dan minatnya masing-masing, mulai dari pertanian, peternakan, perikanan dll. Beliau tidak suka melihat santrinya menganggur atau menggantungkan hidup pada orang lain baik swasta atau pemerintah. Kiai Pud yang mempunyai 20 anak dari 4 istri dan 14 cucu ini tidak bosan menanamkan dan mendoktrin santri untuk menciptakan lapangan pekerjaan. Lebih baik menjadi raja kecil daripada menjadi budak besar, seperti menjadi buruh pabrik atau pegawai negeri.

Disamping bergerak dibidang pendidikan, sumbangsih pesantren ini dibidang kemasyarakatan juga tidak sedikit. Dalam bidang rohani, pesantren ini bisa dikatakan sebagai salah satu pusat pemenuhan kebutuhan rohani untuk masyarakat Pacet dan sekitarnya dengan diadakannya Majelis Ta'lim untuk masyarakat umum 3 kali dalam seminggu, hari Ahad pagi, Selasa sore, dan pengajian khusus ibu-ibu pada hari Jum'at sore dan pengajian bulanan setiap Ahad Legi yang jamaahnya mencapai ratusan orang. Disamping itu juga menerjunkan dai dan khotib ke daerah - daerah di Kecamatan Pacet, sehingga nampak sekali perubahan dan perkembangan keagamaan di Kecamatan Pacet.

\section{Yayasan Bina Insani}

Pondok Pesantren Riyadlul Jannah dikelola dalam tubuh sebuah organisasi dengan nama Yayasan Bina Insani yang memiliki struktrur kepengurusan.

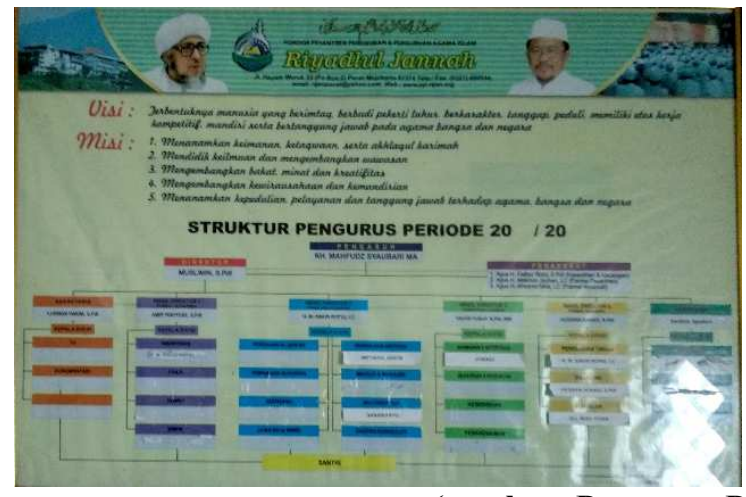

Gambar 1 Struktur Pengurus Pesantren (sumber: Pengurus PP Rijan) 


\section{Rijan Dinamis Selaras}

Pondok Pesantren Riyadlul Jannah atau PP. Rijan juga mengelola usaha bersifat komersil dibawah naungan sebuah entitas usaha berbadan hukum. PT. RIJAN DINAMIS SELARAS (PT RDS) adalah nama perusahaan yang menaungi berbagai jenis usaha. PT RDS yang beralamat di Jln. Hayam Wuruk 22 Pacet Mojokerto ini menaungi usaha yang dijalankan dibidang kuliner, travel, retail, rental, percetakan, wedding organiser, properti, konveksi, home made (cenderamata kerajinan tangan) dan agro industri (perkebunan, peternakan dan perikanan). Unit usaha konveksi atau fashion menggunakan merek dagang "MauRRa", sedangkan usaha kuliner yang sudah dikenal khalayak umum adalah "Dapur M'Riah", Fastfood "M2M" yang lokasi usahanya sudah tersebar di seantero Jawa Timur dan pulau Jawa serta sebagian Sumatera yakni di Jambi yang merupakan kerjasama dengan UIN Jambi. Saat ini jumlah karyawan diseluruh unit usaha mencapai kurang lebih 1000 orang.

Bertindak sebagai presiden komisaris di PT RDS adalah KH. Mahfudz Syaubari, M.A. Pada setiap unit usaha ditempatkan seorang manajer yang diangkat dari keluarga pesantren dengan 3 (tiga ) kriteria : etos, etis dan loyal.

Setiap unit usaha merupakan pusat laba, laporan dari masing-masing unit dilakukan setiap bulan kepada PT RDS, kemudian oleh PT. RDS diteruskan kepada yayasan berupa ringkasan. Laporan bulanan tersebut disampaikan sebelum tanggal 5 bulan berikutnya kecuali laporan harian yang disampaikan 3 (tiga) kali setiap hari untuk diperiksa oleh Komisaris setiap unit usaha. Unit usaha yang sudah memiliki laporan standar adalah unit usaha kuliner, sedangkan unit usaha lain masih bersifat insidental.

Struktur Organisasi dalam PT Rijan Dinamis Selaras (yang saat ini berjalan) sebagaimana bagan berikut ini:

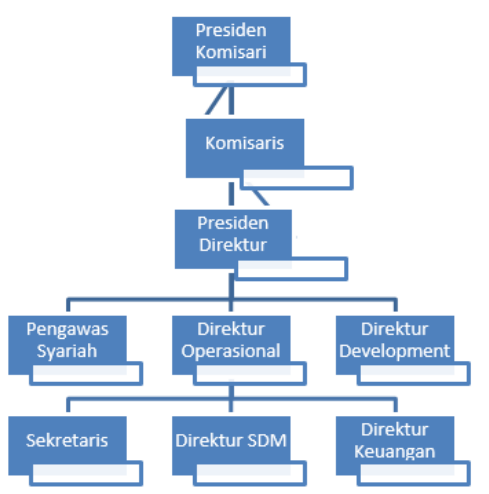

Gambar 2 Struktur Organisasi PT Rijan Dinamis Selaras (sumber: data primer diolah)

\section{Mengenali Tata kelola Di Pondok Pesantren Riyadlul Jannah}

Terdapat 6 karakteristik dalam tata kelola khas pesantren antara lain: transparansi, akuntabilitas, profesionalitas, tanggung jawab sosial, fungsi pengawasan syariah dan adab[19]. Dengan melakukan observasi wawancara kepada informan, yakni Ust H.M. Ainur Rofiq (MAR) dan Gus H. Ahsanul Milal (HAM) pengejawantahan karakteristik di Pondok Pesantren Riyadlul Jannah Pacet dapat dikenali sebagai berikut:

\section{Transparansi.}

Di era digitalisasi dan era teknologi informasi ini sangat mudah untuk menjalankan prinsip transparansi. Informasi mudah diakses dengan jelas, akurat, dan dipahami serta dapat 
dipertanggungjawabkan oleh semua pemangku kepentingan dalam organisasi atau perusahaan tersebut.

\section{Informasi,}

PP Rijan melalui media publikasi berbasis teknologi, yakni website dengan URL www.pp-rijan.ac.id untuk menyebarkan informasi yang berhubungan dengan aktivitas yang dilakukan. Melalui media ini pengelola pesantren Rijan mengomunikasikan kegiatan yang dilakukan. (Lewat laman-laman di website tersebut pengelola pesantren) melakukan penyebaran informasi kepada para pemangku kepentingan. PP Rijan juga mengelola akun resmi instagram dengan ID@pp.rijanpacet.

Melalui laman www.pp-rijan.ac.id yang tampak pada gambar 1 selain itu, Yayasan Bina Insani memberikan informasi tentang aktivitas "Rapat Dewan Guru Dan Dosen ..." agar pemangku kepentingan diantaranya adalah wali santri bisa mengetahui perkembangan kegiatan yang sedang berlangsung di pesantren.

Informasi juga disebarluaskan melalui brosur, yang diletakkan pada papan pengumuman, banner, billboard. Papan pengumuman terletak di ruang terbuka yang mudah diakses oleh publik juga terletak di ruang khusus. Selain informasi yang disebarluarkan melalui media digital, upaya penyebaran informasi dengan menggunakan media konvensional, dicetak dan ditempelkan ditempat publik tetap dilakukan oleh pengelola unit bisnis PP Rijan. Hal ini sebagai upaya agar informasi tetap dapat di akses oleh siapapun yang memerlukan informasi tersebut.

Di tempat usaha yang dimiliki oleh pondok pesantren Rijan juga terdapat papan informasi yang berisi berbagai informasi tentang capaian usaha tersebut, seperti pemilihan karyawan teladan, prestasi gerai seperti yang terpasang di gerai Dapur M'riah di Suko Sidoarjo, Dapur M'riah Bhayangkara Mojokerto, dan M2M di Lebo Sidoarjo serta hal lain terkait usaha tersebut. Informasi tersebut dipampang dalam kurun waktu tertentu meski terkadang tidak diperbaharui dalam jangka waktu yang lama. Agar penyebaran informasi lebih luas, unit bisnis-unit bisnis yang dimiliki oleh PP Rijan pun melakukan pengelolaan penyebaran informasi melalui media sosial. Unit-unit tersebut memiliki akun instagram. Salah satunya@dapurmriahofficial, @m2m.bangkalan,@maurra.id dan akun facebook resmi PP Rijan beralamat https://www.facebook.com/rijan.pacet. Akun Instagram dan Facebook yang dimiliki oleh PP Rijan merupakan upaya memperluas jangkauan penyebaran informasi. Selain itu digunakan oleh alumni untuk tetap terhubung dan mendapat informasi terbaru dari almamater mereka.

\section{Kebijakan}

Berbagai aktivitas yang berlangsung di PP Rijan selain telah dibuat peraturan, juga berjalan dengan kebijakan dimana kebijakan dalam hal-hal strategis dibuat oleh Pengasuh Yayasan Bina Insani (YBI) yang juga sebagai Preskom dalam PT RDS.

Pondok Pesantren Riyadlul Jannah masih dibawah kepemimpinan founder maka beliau sebagai Pengasuh di YBI juga sebagai Preskom di PT RDS, sehingga kebijakan banyak dibuat oleh founder. 


\section{Keputusan}

Sudah menjadi kewajaran apabila dalam sebuah entitas organisasi perlu ada keputusankeputusan yang dibuat. Pondok pesantren Rijan melahirkan keputusan-keputusan yang dibuat oleh pengurus yayasan dan pengelola usaha yang berada di PT RDS. Keputusan operasional sudah dilimpahkan kepada rentang wewenangan dalam struktur organisasi sesuai tupoksinya, kecuali keputusan strategis tetap harus mendapatkan restu dari pengasuh atau Preskom.

\section{Pelaporan}

Pengelolaan Yayasan yang mengoperasionalkan pendidikan setingkat SMP, SMA, Sekolah Tinggi dan Pesantren melaporkan aktivitas operasionalnya secara berkala kepada pengasuh dan kepada pemangku kepentingan sesuai dengan derajat pendidikan formal yang dikelola. SMP dan SMA melaporkan administratifnya kepada dinas terkait, STIE kepada LLDikti dan dikelola sebagaimana standar Dikti seperti akreditasi dan lain-lain.

Pengelolaan usaha yang dijalankan oleh PP Rijan dalam hal pelaporan sudah didukung peran teknologi sehingga dapat disajikan waktu nyata. Tiap-tiap unit bisnis menyampaikan laporannya per bulan ke RDS dan akan diringkas untuk dilaporkan kepada Yayasan. Selain itu pengasuh juga kerap meminta laporan harian kepada pengelola dan melakukan analisis mendeteksi adanya hal yang tidak normal dalam operasional unit bisnisnya terutama yang bergerak di kuliner. Untuk seminggu sekali di hari Selasa diselenggarakan pertemuan di Sidoarjo dalam rangka pelaporan. Dalam hal ini, pengasuh sangat detail dan tegas terkait dengan pelaporan baik pelaporan yayasan maupun pelaporan usaha yang dijalankan.

\section{Pertanggungjawaban}

Pelaksana operasional baik YBI maupun RDS bertanggung jawab kepada pengasuh. Di saat yang sama pengelola usaha juga bertanggung jawab kepada yayasan karena yayasan sebagai payung besar. Pertemuan setiap hari Selasa setiap minggunya terkait dengan bisnis yang dikelola merupakan forum pertanggungjawaban pengelola kepada preskom.

Sementara itu preskom meminta keterangan langsung dari manajer-manajer unit ketika ada yang tidak beres. Hal ini dilakukan agar apabila terdapat anomali yang terjadi pada bisnis yang sedang berjalan bisa segera mendapat intervensi dan penanganan langsung dan segera.

Model transparansi sebagaimana diatas menjadi strategi anti fraud dimana dapat mencegah, mendeteksi dan meminimalisasi terjadinya fraud. Strategi mitigasi fraud bisa berlangsung efektif karena pemilik aset memantau langsung dan memberikan evaluasi serta tindaklanjut apabila seandainya terjadi fraud.

\section{Akuntabilitas}

Didirikannya PT RDS oleh Yayasan Bina Insani merupakan upaya untuk meningkatkan akuntabilitas menjadi lebih baik. Deskripsi tugas sebagian strustur memang masih bersifat arahan langsung dari founder atau disesuaikan dengan kebutuhan di lapangan. Terkadang personal tertentu dengan jabatan tertentu justru memiliki kewenangan dan tanggungjawab lebih luas disebabkan oleh kebutuhan founder. Kondisi ini mungkin terjadi sebab pemegang amanah dipilih berdasarkan kepercayaan dan pengalaman.

Menurut kaidah tata kelola yang baik, pemisahan struktur harus diikuti pemisahan personil. Pondok Pesantren Rijan masih memiliki keterbatasan pada personil sehingga masih 
ada amanah yang rangkap. Seseorang mendapat amanah sebagai Dewan Penasehat di YBI sementara di PT RDS sebagai pengawas syariah.

Hal ini bukan tanpa maksud, semata untuk menjaga agar visi dan tujuan pesantren antara bisnis dan non bisnis tetap selaras. Dikhawatirkan apabila tidak dirangkap atau diserahkan kepada orang yang dalam hal ini profesional murni maka orientasi pengabdian dan dakwah akan terabaikan karena tidak mengikuti dan mengenal sejarah dan visi pesantren.

Melalui pemisahan antara YBI dan RDS dengan rentang kendali masing-masing, meskipun terdapat rangkap amanah, dimungkinkan terjadi pengendalian internal, karena saling silang jabatan atau amanah di YBI dan RDS. Fraud di kedua organisasi dapat diminimalisasi setidaknya selalu dalam pantauan founder, karena founder bertindak sebagai pengasuh di YBI dan Preskom di RDS.

\section{Profesionalitas}

Dalam pandangan orang awam terkadang menilai bahwa mereka yang mengelola pesantren hanya mengerti kitab kuning atau ilmu agama, sedangkan ilmu bisnisnya tidak. Tidak demikian halnya dengan yang terjadi di Pondok Pesantren Rijan ini. Karyawan yang berjumlah 1000 orang menandakan bahwa usaha yang dikelola tidak main-main. Jasa perjalanan wisata umroh saja mampu memberangkatkan 4 kali jamaah umroh dalam setahun.

Tentu saja bisnis yang lain lebih baik lagi, hingga saat ini bisnis kuliner yang dikelola oleh PP Rijan ini makin berkembang. Ada saja bisnis baru yang dibuka. Profesionalime yang khas yang dapat ditemukan adalah menerapkan asas pengabdian dan keberkahan yang dipadu dengan keahlian dan kompensasi.

Kembali kepada kriteria pemilihan yang ditetapkan oleh pengasuh pondok (Abuya) yakni etis, etos dan loyal maka profesionalisme para pengelola usaha di PP Rijan memiliki nilai unik (uniquelly value) dan skill teknis dibarengi dengan moral dan dedikasi.

Dengan meletakkan orang yang amanah melalui filter kriteria etis, etos dan loyal, stake holder dapat berharap bahwa strategi antifraud dapat berjalan. Pelaku fraud tidak mudah terbentuk disebabkan oleh pelaku loyal, beretika dan ber etos kerja.

\section{Tanggungjawab Sosial}

Pemangku kepentingan sebuah entitas organisasi atau usaha yang beroperasi di wilayahnya diharapkan dapat menumbuhkan ketenangan, kepedulian dan kebaikan (rahmat).

Keberadaan PP Rijan bagi masyarakat di sekitar tempat berdirinya pondok dirasakan manfaatnya, terutama bagi dhuafa yang membutuhkan pendidikan secara cuma-cuma. Peningkatan omset saat ada event dirasakan oleh pengusaha kuliner disekitar pondok pensantren. Lapangan kerja bagi masyarakat sekitar juga terbuka dan bertambah bisa sebagai tenaga edukasi (guru/ustaz/ustazah) atau tenaga operasional (parkir, petugas taman dll).

Suasana religius juga tampak di kawasan Pacet yang dahulu dikenal sebagai kawasan mesum. Kini dimana-mana di wilayah Pacet nampak santri ber peci putih yang lalu lalang dijalan, suara orang ngaji, wirid dan membaca sholawat. Iklim usaha juga tumbuh baik usaha komersil maupun usaha pemberdayaan yang dilakukan oleh pondok dengan melakukan kerjasama gaduh/merawat sapi dengan masyarakat di sekitar pondok. 


\section{Fungsi Pengawasan Syariah}

Tampak bagan organisasi PT RDS terdapat pengawas syariah yang memberikan kepastian compliance/kepatuhan dalam pelaksanaan syariah pada bisnis-bisnis yang dikelola oleh PP Rijan. Kepatuhan terhadap syariah dalam bisnis-bisnisnya dalam pengawasan dan evaluasi setiap saat meski tidak secara eksplisit dituangkan dalam akta perusahaan.

Dengan menelaah sebelum bisnis tersebut dijalankan, akan memberikan kepastian tata kelola yang baik dan mencirikan bahwa bisnis tersebut dikelola oleh mereka yang memahami syariat agama. Dan model semacam ini menjadikan bisnis yang dijalan oleh ponpes Rijan sangat unik, modern yang tetap syar'i. Tata kelola semacam ini meningkatkan nilai bisnis dan diminati oleh investor yang sensitif terhadap nilai religius.

Sudah tentu dengan dijalankannya kepengawasan syariah, memberikan harapan semakin kecil kemungkinan terjadinya fraud dalam pelaksaan pengelolaan usaha. Nilai religius akan menjadi pengendali pengelola untuk menghindarkan diri dari tindakan fraud.

Fungsi pengawasan syariah ini merupakan strategi anti fraud. Sebagai bentuk mitigasi, pencegahan sebelum fraud dimungkinkan terjadi serta pemantauan untuk mengurangi kesempatan fraudster melakukan aksinya.

\section{Adab}

Pesantren sebagai tempat nyantri atau mencari ilmu keagamaan tidak bisa ditinggalkan. Nilai-nilai yang ditanamkan pada kepada para santri sudah barang tentu memberi warna pada pola tata kelola usaha yang dijalankan. Nilai-nilai tersebut termasuk pola ber perilaku baik atau akhlakul karimah yang ditanamkan sebagai adab atau tatanan. Pola edukasi yang paling efektif adalah memberi contoh atau teladan, sehingga sebagian pengelola bisnis milik pondok pesantren yang juga memiliki peran sebagai pengajar di pesantren harus menjalankan nilainilai adab, akhlakul kariim sebagai upaya memberi teladan kepada santri mereka. Sudah barang tentu akhlakul kariim ini menjadi jiwa setiap anggota pesantren tidak terkecuali pengelola bisnis, ustadz/ustadzah di pesantren Rijan.

Pesantren membekali santri-santri dengan ilmu yang bersumber dari kitab Ta'lim Muta'allim dan akhlaq lil banin wa lil banat. Kitab Ta'lim Muta'alim terdiri dari tiga belas pasal pelajaran dimana salah satu pelajaran diantaranya menjadi cerminan tata kelola yang baik yakni pelajaran tatanan untuk bekerja dengan "tidak tamak" [28]. Bekal ilmu dari kitab ini yang mengajarkan bahwa menuntut ilmu dan fiqh bisa dilakukan bersama dengan bekerja mencari uang tetapi juga disertai kebaikan perilaku atau akhlakul kariim. Tatanan sedemikian ini akan menjiwai pengelola bisnis menjalankan usahanya dengan tata kelola yang baik.

Pengasuh memberikan pula pesan berupa nilai-nilai kebaikan yang ditanamkan kepada santri asuhannya. Abuya Kyai Mahfud memberikan ajaran nilai-nilai akhlak yang disarikan dari kitab Akhlak Lil Banin [29]. Nilai-nilai ini yang mengejawantah menjadi tatanan hidup dan tatanan lain termasuk pengelolaan bisnis. Pesan tersebut diantaranya ada Tekad Santri; Santri Sejati; Ikrar Santri dan Aroma Surga.

Nilai-nilai tersebut terus menerus didengungkan dipenjuru pesantren melalui media tulisan dan poster yang terpasang diberbagai sudut ruang aktivitas. Karena disampaikan berulang-ulang maka pesan tentang adab tersebut melekat dan mendarahdaging dalam keseharian gerak langkah penghuni pesantren termasuk didalamnya para pengelola bisnis pesantren. 
Bila akhlak dan perilaku pelaksana atau pengelola bisnis baik, dan memiliki pengawasan melekat yakni Sang Khaliq sudah barang tentu ini adalah anti fraud paling mujarab. Pribadi yang shaleh dan berorientasi tidak semata materi akan membawa pada pelaksanaan pengelolaan usaha yang amanah sesuai harapan pemangku kepentingan.

\section{Tata Kelola Pondok Pesantren Riyadlul Jannah}

Sebagaimana pondok pesantren lain pada umumnya, Riyadlul Jannah sebagai tempat belajar mengajar ilmu agama, belajar tata nilai (salaf), dan pendidikan formal yang juga memiliki ciri pondok yaitu asrama atau tempat tinggal santri sementara saat menempuh pendidikan [16]. Secara kelembagaan aktivitas belajar mengajar mulai tingkat SMP hingga perguruan tinggi di pesantren ini dinaungi oleh sebuah organisasi berbentuk yayasan yang bernama Yayasan Bina Insani (YBI). Personalia yang ada dalam struktur organisasi YBI merupakan komposisi keluarga pendiri pondok (anak, menantu, kerabat dekat) dan sedikit personal diluar kekerabatan. Hal ini bertujuan untuk tetap menjaga sejarah dan visi pondok pesantren. Mengingat awalnya semua kebutuhan yang berhubungan dengan pembelajaran, tanah, pembangunan fasilitas dan infrastruktur serta operasional sebagian besar masih disediakan dan dipenuhi oleh Kyai dan merupakan aset keluarga [30].

Selain mengelola kegiatan belajar mengajar kesantrian, pondok pesantren Rijan juga memiliki sejumlah aktivitas usaha komersial. Kelembagaan yang menaungi aktivitas bisnis komersil PP Rijan adalah sebuah organisasi berbentuk perseroan terbatas yang bernama PT Rijan Dinamis Selaras (RDS). Hasil dari aktivitas usaha komersial inilah yang digunakan sebagian untuk membiayai kegiatan pesantren dibidang pendidikan. Mengapa demikian?karena banyak diantara santri yang belajar atau menempuh pendidikan di PP Rijan ini tidak mampu memenuhi biaya yang dibutuhkan, sehingga perlu subsidi silang dan upaya lain untuk menutup overhead tersebut. Memberikan beasiswa atau menggratiskan biaya kepada santri di hampir setiap tahun ajaran baru untuk belajar di PP Rijan di setiap jenjang pendidikan yang ada disini.

Saat ini PP Rijan menjadi institusi yang besar dan berkembang ditengah masyarakat dan bisa disebut sebagai pondok pesantren modern[2]. Peran sentral Kyai di PP Rijan masih sangat kental dan mewarnai setiap lini dan aspek aktivitas yang dilakukan baik dalam operasional pondok sebagai lembaga edukasi maupun pengelolaan bisnis yang sangat banyak variasi dan lini usahanya. Walau demikian seperti yang dikatakan Jamaluddin, PP Rijan masih mampu melakukan adaptasi dan melakukan metamorfosis sesuai dengan perkembangan masyarakat modern[3].

\section{Transparansi}

Keterbukaan di era teknologi informasi ini sangat mudah dicapai. Dalam rangka menjaga objektivitas pengelolaan kegiatan, tak hanya terbatas pada transparan yang bernilai material saja yang dilaksanakan oleh pengelola. Pengelola PP Rijan melaksanakan keterbukaan dan transparansi dalam informasi, kebijakan, keputusan, pelaporan dan pertanggungjawaban. Hal ini bersesuaian dengan Principles of Corporate Governance yang dibuat oleh OECD tentang disclosure and transparency yang mana informasi dimaksud termasuk tujuan perusahaan, isu terkait karyawan dan transaksi pihak lain yang terkait, dalam hal ini santri [31]. Keterbukaan terkait informasi, kebijakan, keputusan, pelaporan dan pertanggungjawaban disampaikan oleh pengelola lewat berbagai media yang memungkinkan untuk dicapai. 
Terkait dengan audit tahunan yang diselenggarakan oleh pihak independen, kompeten dan kualifikasi. PP Rijan belum melaksanakan kegiatan audit tahunan oleh pihak independen. Hal ini disebabkan oleh pemangku kepentingan masih bermuara dan dominasi pada pusat tunggal yakni pendiri. Sehingga dalam rangka untuk memberikan jaminan eksternal dan objektif kepada pemangku kepentingan bahwa laporan keuangan cukup mewakili posisi keuangan dan kinerja perusahaan dalam semua hal yang material, belum dapat dicapai.

Transparansi yang dipraktikkan entitas bisnis pada umumnya juga berbatasan dengan rahasia perusahaan. Meskipun transparansi menjadi hak pemangku kepentingan, tetapi perusahaan wajib menyampaikan dengan benar. Akan tetapi, transparansi hanya diberikan pada pemangku kepentingan sebatas tanggung jawab perusahaan. Tidak semua hal harus dijelaskan terbuka selebar-lebarnya.

Perusahaan hanya berkewajiban untuk terbuka dan memberikan informasi kepada pemangku kepentingan sebatas yang dijanjikan, dikomitmenkan, atau yang diatur oleh undang-undang dan hukum. Dalam laporan pelaksanaan GCG, transparansi disampaikan sebagai sebuah hal normatif. Sebagaimana dalam salah satu laporan pelaksanaan GCG milik sebuah entitas perbankan, transparansi yang dilaporkan lebih pada pernyataan sikap normatif. Untuk menjadi sebuah integritas sikap masih memerlukan pembuktian dan konfirmasi positif berkaitan dengan pernyataan transparansi diatas.

\begin{abstract}
Akuntabilitas
Prinsip dasar akuntabilitas menurut KNKG adalah perusahaan harus dapat mempertanggungjawabkankinerjanya secara transparan dan wajar. Berpedoman pada pokok pelaksanaan perusahaan harus menerapkan rincian tugas dan tanggung jawab masing-masing organ perusahaan dan semua karyawan secara jelas dan selaras dengan visi, Preskom perusahaan milik PP Rijan dalam melakukan pemilihan personalia yang akan mengemban tugas sebagai manajer menggunakan tiga kriteria etos, etis dan loyal.

Meskipun diangkat dari keluarga pesantren, kriteria tersebut wajib dipenuhi dalam rangka menjaga misi, nilai-nilai perusahaan (corporate value), dan strategi perusahaan. Menjaga marwah pesantren masih diperlukan (orang dalam) agar mengetahui sejarah, visi dan orientasi pesantren tanpa meninggalkan kaidah. Dengan demikian setiap orang yang menjadi organ perusahaan dan semua karyawan mempunyai kemampuan sesuai dengan tugas, tanggung jawab, dan perannya dalam perusahaan.

Dalam konsep transparansi, praktik umum yang dilakukan entitas bisnis pada umumnya adalah kemampuan organisasi dan perusahaan untuk mampu menjawab segala pertanyaan yang akan diajukan oleh para pemangku kepentingan atas apa yang telah diperbuat dan hasil yang dicapai oleh organisasi atau perusahaan itu sendiri. Melalui forum pertemuan setiap Selasa di Sidoarjo, pengelola bisnis PP Rijan menjalankan praktik tersebut.

Sementara entitas bisnis yang sudah mapan melakukan praktiknya dengan menyampaikan laporan penerapan GCG dalam korporasinya. Disampaikan secara annual dalam bentuk manuskrip laporan pelaksanaan GCG, sebagaimana dilakukan oleh PT Bank Negara Indonesia (Persero) Tbk menguraikan penerapan prinsip GCG-nya dalam laporan tahunan sebagaimana gambar dibawah ini:

Memang pembandingan ini tidak apple to apple, tetapi sebagai sebuah entitas bisnis, PT RDS menerapkan sebagian dari prinsip dasar pelaksanaan akuntabilitas dalam upaya implementasi tata kelola yang baik.
\end{abstract}

\title{
Resposibilitas/Tanggung jawab
}




\section{Independensi}

Perusahaan harus dikelola secara independen sehingga masing-masing organ perusahaan tidak saling mendominasi dan tidak dapat diintervensi oleh pihak lain ini merupakan prinsip dasar pelaksanaan tata kelola yang baik menurut KNKG .YBI dan PT RDS meskipun memiliki personalia yang sama dan Kiai sebagai puncak pimpinan, kedua organisasi tersebut berjalan seiring saling mendukung, tidak tumpang tindih karena pada prinsipnya personalia organisasi bukan memegang jabatan juga mengemban amanah kyai yang menjadi i'tibar. Kiai Pud sebagai pengasuh dan preskom pun menjadi pengendali agar tidak terjadi benturan kepentingan antar organ perusahaan. Beliau orang yang memegang prinsip bebas pengaruh kepentingan pihak tertentu dan tidak ada vested interest dengan pihak manapun sehingga pengambilan keputusan tetap dapat diambil secara objektif.

Orang-orang disekitar Abuya (Kyai Mahfud) adalah orang-orang pilihan dengan tiga kriteria etos, etis dan loyal memegang amanah yang diberikan sesuai arahan dan tidak saling melempar tanggung jawab. Meskipun deskrisi tugas sering berbeda dengan job title karena disesuaikan dengan kebutuhan dan instruksi Abuya. Sepanjang tetap dalam koridor syariah dan ketentuan normatif yang berlalu, fenomena ini masih bernilai independen

Dengan bentuk indepensi yang dikembangkan sebagaimana fenomena di PP Rijan, independent but dependent. Independen dalam arti bebas dari intervensi pihak lain dan tidak selalu bergantung pada pihak lain tetapi berada dalam kendali pihak yang menjaga visi PP Rijan dalam mengembangkan kegiatan usaha.

Dikomparasikan dengan pelaksanaan independensi oleh entitas bisnis lain pada umumnya memang terdapat kesenjangan Independensi utuh, dan bebas intervensi sepenuhnya dilaksanakan oleh entitas dengan akuntabilitas publik penuh seperti PT BNI Persero Tbk.

\section{Fairness}

Asas kewajaran menurut KNKG memiliki prinsip dasar yakni dalam melaksanakan kegiatannya, perusahaan harus selalu memperhatikan kepentingan pemilik andil dan pemangku kepentingan lainnya berdasarkan asas kewajaran dan kesetaraan. Oleh karena kebanyakan aset bisnis dibawah naungan PT RDS masih berasal dari keluarga dalam pesantren, sebagian kecil saja yang merupakan kerjasama dengan pihak lain, dimana pihak tersebut notabene juga alumni pesantren maka secara normatif kepentingan para pemangku kepentingan masih diwadahi dengan adanya pertemuan setiap hari Selasa di salah satu kota di Jawa Timur, di Sidoarjo tepatnya. Pertemuan ini guna membahas perkembangan bisnis, menerima dan menyampaikan laporan-laporan kegiatan, melakukan evaluasi serta merencanakan strategi kedepan. Hal ini dapat dimaknai bahwa perusahaan memberikan kesempatan kepada pemangku kepentingan untuk memberikan masukan dan menyampaikan pendapat bagi kepentingan perusahaan serta membuka akses terhadap informasi sesuai dengan prinsip transparansi dalam lingkup kedudukan masing-masing [32].

Prinsip kewajaran masih dapat dipenuhi oleh PT RDS dengan memberi ruang untuk memberi perhatian pada kepentingan para pemegang saham dan para pemangku kepentingan dalam kewajaran yang normatif. 
Praktik baik penerapan GCG pada prinsip Fairness ini jika merujuk pada laporan penerapan GCG oleh PT BNI Persero Tbk, apa yang dilaksakan oleh PT RDS tidaklah terlalu jauh kesenjangan yang terjadi.

Dalam laporan disebutkan bahwa bank memperhatikan kepentingan seluruh stakeholder asas kesetaraan dan kewajaran (equal treatment). Demikian pula PT RDS dalam pertemuan bisnis yang diselenggarakan Selasa setiap minggunya di Sidoarjo.

\section{Local Wisdom dalam Tata Kelola di Pesantren Riyadlul Jannah}

Lima prinsip dasar azas penerapan GCG atau yang kerap disebut lima pilar GCG telah diuraikan dalam pembahasan sebelumnya. PP Rijan memiliki tambahan prinsip tata kelola yang baik dan merupakan kearifan lokal [19].

\section{Profesionalitas}

Karakter profesionalitas ini adalah dalam struktur maupun operasional terjaga dengan menerapkan azas pengabdian dan keberkahan[19]. Konteks profesionalitas merupakan perpaduan antara keahlian dan kompensasi. Profesionalitas bisnis dan pengelolaan lembaga membutuhkan orang yang ahli dan orang ahli menuntut keselarasan kompensasi. Konteks ini tidak diterapkan pada pesantren karena keahlian berbasis kompensasi dan sebaliknya tidak selaras dengan misi pesantren bahwa setiap tugas (khidmah) bagian dari pengabdian dan pengabdian (diyakini) akan memberikan keberkahan.

Sumberdaya manusia yang mengelola Yayasan Bina Insani dan PT Rijan Dinamis Selaras rerata merupakan santri, alumni santri atau keluarga dalem pesantren. Melihat latar belakang asal-usul personalia yang memiliki landasan religius yang baik dan berasal dari internal pesantren, sehingga masalah pengabdian tidak perlu lagi dipertanyakan. Stereotype dan rasa cinta almamater tentu melekat, ditunjang pemilihan personal berdasarkan 3 kriteria etos,etis dan loyal.

Faktor keberkahan juga merupakan hal yang tidak perlu diragukan lagi, mengingat keberadaan usaha yang dijalankan pondok mensyarakat penyisihan sebagian keuntungan untuk disalurkan sebagai zakat, infaq dan shodaqoh. Ketentuan ini menjadi aturan bagi semua unit bisnis dibawah naungan PT RDS. Tidak setiap entitas usaha mampu membangun dua nilai ini yaitu pengabdian dan keberkahan tanpa motivasi materi yang cukup. PP Rijan mampu menyelenggarakan asas profesionalitas dengan berlandaskan pengabdian dan keberkahan.

\section{Pengawasan Syariah}

Alim \& Rahman (2018) mendefinisikan pengawasan syariah ini adalah kepatuhan syariah yang melekat dalam proses penatakelolaan pesantren dan dengan lembaga maupun bisnisnya meskipun tidak terformalisasi dalam struktur. Sebagian pengawasan kepatuhan terstruktur Dewan Pengawas Syariah (DPS) dan sebagian berjalan secara fungsi. Namun demikian unit-unit bisnis yang secara legal formal membutuhkan legalitas syariah (sertifikasi syariah untuk hotel, lembaga keuangan, klinik dan rumah sakit dan sertifikasi halal untuk bisnis makanan/obat-obatan/pakaian) maka sebaiknya DPS terstruktur secara formal dan personelnya bersertifikasi sesuai dengan ketentuan peraturan karena selain memberikan jaminan juga mengurangi unsur gharar.

PP Rijan pada beberapa unit bisnis yang akan dijalankan atau yang telah dijalankan, sudah melalui kajian sharia compliance yang dilakukan oleh Dewan Syariah. Hal ini mencerminkan bahwa Dewan Syariah tidak hanya berfungsi saat bisnis berjalan, tetapi masa 
pra bisnis dijalankan, dewan syariah di PT RDS sudah menjalankan fungsinya. Akan tetapi keberadaan Dewan Syariah ini tidak mengekang elastisitas pelaksanaan rencana usaha. Keberadaan Dewan Syariah sebagai fungsi menjaga agar bisnis tetap berada pada koridor yang tidak melanggar syariah namun tidak pula menjadi tali kekang yang menghambat gerak laju pertumbuhan bisnis yang adaptif terhadap pertumbuhan dan perkembangan jaman.

\section{Adab}

Nilai-nilai akhlakul kariim , budi pekerti luhur, tata krama, sopan santun, merupakan pembeda manusia berADAB dan tidak memiliki perADABan. Santri di PP Rijan mendapat gemblengen dan doktrin melalui pengajian dan majelis ilmu tentang adab ini. Menggunakan sumber kitab Ta'lim Muta'allim dan Kitab Akhlak lil banin wa lil Banat dimana di dalam kedua kitab tersebut diajarkan etika dalam hidup sehingga konsep adab bisa juga disetarakan sebagai etika.

Prinsip ini mengejawantah dalam pelaksanaan pengelolaan bisnis yang dijalankan oleh PP Rijan. Bisnis di PP Rijan tidak semata mengejar keuntungan semata tetapi juga menjalankan fungsi education, social \& sharing. Fungsi edukasi bagi santri dan menjadi laboratorium hidup untuk menempa jiwa kewirausahaannya. Fungsi sosial dimana ada kewajiban menyisihkan keuntungan untuk infaq, zakat dan shodaqoh. Fungsi sharing, santri bisa ikut memiliki bisnis yang dijalankan dan tempat santri tersebut ikut menjadi operatornya.

Secara modeling tata kelola yang dikembangkan dalam pengelolaan kegiatan di PP Riyadlul Jannah Pacet Mojokerto dapat direpresentasikan sebagaimana model berikut ini:

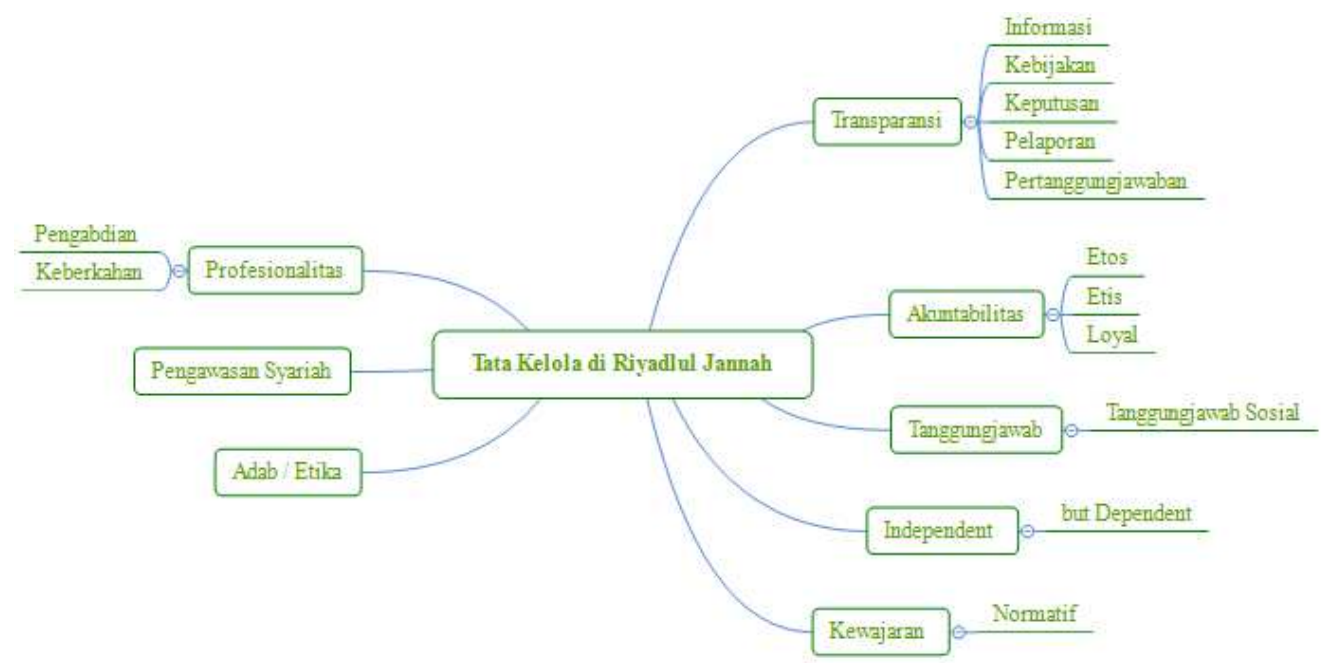

Figure 3 Model Tata Kelola di PP Rijan (sumber: diata diolah)

\section{Kesimpulan}

Karakteristik model tata kelola khas pesantren yang mengelola berbagai macam usaha komersial tidak meninggalkan asas tata kelola yang baik menurut Komite Nasional Kebijakan Governance yaitu transparansi, akuntabilitas, tanggungjawab/responsibilitas. Sementara asas independesi dan kewajaran belum dapat diterapkan secara murni mengingat keberadaan pondok pesantren Rijan masih banyak dominasi oleh pendiri atau founder karena dominasi 
aset merupakan penyisihan aset founder atau keluarga pesantren. Hal tersebut dapat dimaklumi disebabkan oleh karakter struktur kepemilikan yang ada di pondok pesantren Rijan belum sepenuhnya murni entitas berakuntabilitas publik. Kecendurungan family business dan family assets.

Instrumen tata kelola yang khas pondok pesantren dalam mengelola kelompok usaha yang berbasis religiusitas nampak terdapat kearifan lokal. Terdapat 4 pilar yang merupakan value unik yaitu profesionalitas, tanggungjawab sosial; fungsi pengawasan syariah dan adab. Empat komponen tata kelola khas yang memuat kearifan lokal sarat dengan nilai-nilai religius, tatanan kesolehan dan ubudiyah ghoiru magdhoh menjadi cermin model Good Governance ala pesantran. Model tata kelola khas yang memuat kearifan lokal ala pesantren memiliki peran dalam upaya pencegahan fraud. Mitigasi fraud sebagai wujud strategi antifraud pengelola tidak harus diawasi agar takut untuk tidak melakukan fraud.

\section{References}

[1] M. Noeng, "Ilmu Pendidikan dan Perubahan Sosial: Suatu Teori Pendidikan." Yogyakarta: Sarasehan, 1987.

[2] G. A. N. Zakaria, "Pondok Pesantren : Changes and Its Future," Journal of Islamic and Arabic Education, vol. 2, no. 2, hal. 45-52, 2010.

[3] M. Jamaluddin, "Metamorfosis Pesantren Di Era Globalisasi," KARSA: Jurnal Sosial dan Budaya Keislaman, vol. 20, no. 1, hal. 127-139, 2012.

[4] Republika, "Pesantren jatim bentuk sarekat bisnis.pdf," www.republika.co.id, 2017. [Daring]. Tersedia pada: http://www.republika.co.id/berita/ekonomi/syariahekonomi/17/11/08/oz25vu423-pesantren-di-jatim-bersinergi-bentuk-sarekat-bisnis. [Diakses: 06-Feb-2018].

[5] S. N. Azizah, "Pengelolaan Unit Usaha Pesantren Berbasis Ekoproteksi," Ekbisi, vol. IX, no. 1, hal. 103-115, 2014.

[6] Ikatan Akuntan Indonesia dan Bank Indonesia, Pedoman Akuntansi Pesantren, 1st ed. Jakarta: Bank Indonesia, 2017.

[7] Komite Nasional Kebijakan Governance, Pedoman Good Corporate Governance Perbankan Indonesia. Jakarta: Komite Nasional Kebijakan Governance, 2010.

[8] T. S. Kaihatu, "Good corporate governance dan penerapannya di indonesia," Jurnal Manajemen dan Kewirausahaan, vol. 8, no. 1, hal. 1-9, 2006.

[9] S. Ngumar, "Menuju Good Governance Bagi Pemerintahan dan Perusahaan," EKUITAS, vol. 5, no. 4, hal. 341-355, 2001.

[10] D. Miller dan I. L. B. Miller, "Family Governance and Firm Performance," Familiy Business Review, vol. 19, no. 1, hal. 73-87, 2006.

[11] N. Huda, D. Anggraini, N. Rini, H. Hudori, dan Y. Mardoni, “Akuntabilitas Sebagai Sebuah Solusi Pengelolaan Wakaf,” Jurnal Akuntansi Multiparadigma, vol. 5, no. 3, hal. 485-497, 2014.

[12] A. Safieddine, "Islamic financial institutions and corporate governance: New insights for agency theory," Corporate Governance, vol. 17, no. 2, hal. 142-158, 2009.

[13] R. Oktafia dan A. Basith, "IMPLEMENTASI GOOD CORPORATE GOVERNANCE PADA PONDOK PESANTREN SEBAGAI UPAYA PENINGKATAN DAYA SAING," Jurnal Ekonmi Islam, vol. 8, no. 1, hal. 71-86, 2017.

[14] C. Anwar, "Methodological Perspective in Constructing Spirituality and Dignity-Based Accounting.pdf," Jurnal Akuntansi Multiparadigma, vol. 3, no. 2, hal. 255-271, 2012. 
[15] PP Rijan Online, "PP-RIJAN," www.pp-rijan.ac.id, 2017. [Daring]. Tersedia pada: http://www.pp-rijan.ac.id/2017/08/sekolah-tinggi-ilmu-ekonomi.html. [Diakses: 24-Jan2018].

[16] A. R. Reginald, "KEWIRAUSAHAAN SOSIAL PADA PONDOK PESANTREN SIDOGIRI PASURUAN," Jurnal Ekonomi Syariah Teori dan Terapan, vol. 1, no. 5, hal. 333-345, 2014.

[17] Komite Nasional Kebijakan Governance, Pedoman Umum Good Corporate Governance Indonesia, 2 ed. Jakarta: Komite Nasional Kebijakan Governance, 2006.

[18] Komite Nasional Kebijakan Governance, GOOD PUBLIC GOVERNANCE INDONESIA. Jakarta: Komite Nasional Kebijakan Governance, 2008.

[19] M. N. Alim dan A. Rahman, "Identifikasi Dan Formulasi Tata Kelola (Governance) Dan Kinerja Pesantren Multi Sosial Bisnis Dalam Perspektif Syariah," 2018.

[20] O. Renny dan A. Basith, "Good corporate governance," Jurnal Ekonmi Islam, vol. 8, no. 1, hal. 71-86, 2017.

[21] M. N. Alim, "Regulasi dan Reposisi Zakat," in Muhasabah Keuangan Syariah, Solo: PT Aqwam, 2011, hal. 183.

[22] M. N. Alim, "Utilization and Accounting of Zakat for Productive Purposes in Indonesia: A Review," Procedia - Social and Behavioral Sciences, vol. 211, no. September, hal. 232-236, 2015.

[23] A. Emilia Sula Moh Nizarul Alim Prasetyono, "Pengawasan, Strategi Anti Fraud, Dan Audit Kepatuhan Syariah Sebagai Upaya Fraud Preventive Pada Lembaga Keuangan Syariah,"JAFFA Oktobe, vol. 02, no. 2, hal. 91-100, 2014.

[24] ACFE, "Fraud Examiners Manual," 2014 International Edition, 2014.

[25] Bank Indonesia, Penerapan Strategi Anti Fraud bagi Bank Umum, no. 13. Indonesia, 2011.

[26] C. Tri, "Memahami Lebih Lanjut Penerapan Strategi Anti Fraud Bagi Bank Umum Di Indonesia," Dinamika Akuntansi Keuangan dan Perbankan, vol. 1, no. 2, hal. 159-174, 2012.

[27] A. E. Sula, M. N. Alim, dan Prasetyono, "Pengawasan, Strategi Anti Fraud, Dan Audit Kepatuhan Syariah Sebagai Upaya Fraud Preventive Pada Lembaga Keuangan Syariah," JAFFA, vol. 02, no. 2, hal. 91-100, 2014.

[28] M. S. bin A. bin M. bin A. Rangkul, Terjemahan Kitab Ta 'limul Muta'alim Thariqatta'allum. Pelita Penuntut Ilmu, 2012.

[29] U. I. A. Barja, Terjemah Akhlak Lil Banin Juz 1, 1 ed. Mojokerto: MADIN SMP 8 Mojokerto.

[30] M. N. Alim dan A. Rohman, "2018 THE GOVERNANCE TYPE OF PONDOK PESANTREN' S BUSINESS UNIT AND," South East Asia Juornal of Contemporary Business, Economics and Law, vol. 17, no. 2, hal. 56-62, 2018.

[31] OECD, OECD Principles of Corporate Governance. Perancis: OECD Publications, 2004.

[32] Komite Nasional Kebijakan Governance, "Pedoman Umum Good Corporate Governance Indonesia," Pedoman Umum Good Corporate Governance Indonesia, hal. 30, 2006. 